\title{
Manure nutrient application on a Chinese dairy farm with arable land: A case study based on Dutch experience of equilibrium fertilization
}

\author{
Roland W. Melse ${ }^{1 *}$, Fridtjof E. de Buisonjé ${ }^{1}$, Qiao Wei ${ }^{2}$, Dong Renjie ${ }^{2}$ \\ (1. Wageningen University \& Research, Wageningen Livestock Research, 6700 AH, Wageningen, the Netherlands; \\ 2. Biomass Engineering Center, College of Engineering, China Agricultural University, Beijing 100083, China)
}

\begin{abstract}
For a Chinese dairy farm with 2200 milking cows, the annual manure production and manure nutrients (nitrogen and phosphorus) were estimated. Gaseous nitrogen losses from cattle housing with scraped solid floors were based on on-farm measurements. Based on experiences from the Netherlands, nutrient levels in the solid and liquid fractions after slurry separation were estimated. On the basis of assumptions for nutrient losses during covered lagoon storage and land application of the liquid fraction, nitrogen and phosphorous fertilization rates were calculated for the $67 \mathrm{hm}^{2}$ of agricultural land that receive the liquid fraction by gravity irrigation. The results show that the application rates of nitrogen and phosphorous significantly exceed the crop needs, which will probably result in losses to soil and water. In order to aim for a balance between nutrient application and crop needs and, as such, reduce environmental harm, the authors recommend to establish application standards for nitrogen and phosphorous on arable land in China and to formulate farm-specific Nutrient Management Plans.
\end{abstract}

Keywords: dairy manure, nutrient balance, dairy farm, over-fertilization, nutrient application standard, environmental protection

DOI: $10.25165 / \mathrm{j}$.jjabe.20171004.3082

Citation: Melse R W, de Buisonjé F E, Qiao W, Dong R J. Manure nutrient application on a Chinese dairy farm with arable land: A case study based on Dutch experience of equilibrium fertilization. Int J Agric \& Biol Eng, 2017; 10(4): 182-188.

\section{Introduction}

With the rapidly increasing livestock production in China, the manure production is increasing at a similar pace. Because of the imbalance between large scale livestock farms and small scale arable farms, manure distribution is difficult, causing local and regional manure

\section{Received date: 2017-01-02 Accepted date: 2017-05-31}

Biographies: Fridtjof E. de Buisonjé, BSc, Technical Researcher, research interests: livestock, manure, environment, Email: fridtjof.debuisonje@wur.nl; Qiao Wei, PhD, Associate Professor, research interest: anaerobic digestion, Email: qiaowei@cau.edu.cn; Dong Renjie, PhD, Professor, research interest: biogas technology, Email: rjdong@cau.edu.cn.

*Corresponding author: Roland W. Melse, PhD, Senior Researcher, research interests: emission abatement, manure treatment, Wageningen University \& Research, Wageningen Livestock Research, P.O. Box 338, 6700 AH, Wageningen, the Netherlands. Tel: +31-(0)317-480285, Email: roland.melse@wur.nl. surpluses. Furthermore, the lack of appropriate equipment for land application of liquid manure (slurry) and the absence of legal manure nutrient application standards are risk factors for the occurrence of manure dumping and excessive fertilization (i.e. the application of large volumes of slurry on small plots of land, thus posing a threat to both surface and ground water quality ${ }^{[1-3]}$.

In 2013, the Sino-Dutch Dairy Development Centre (SDDDC, www.sdddc.org) was established which aims to exchange knowledge and technology on dairy production between China and the Netherlands, taking into account both economics and environmental protection. Within this framework a case study was carried out on a Chinese dairy farm with arable land.

The aim of this study was to provide insight into the manure and nutrient flows on this farm and to calculate 
land application rates for nitrogen and phosphorus (or phosphate or $\mathrm{P}_{2} \mathrm{O}_{5}$, is based on the analyzed phosphorus content and calculated as $2.29 \times \mathrm{P}$-content.). This was done by studying the current practices and manure management system on the farm and by comparing the results with equilibrium fertilization standards that are used in the Netherlands.

\section{Description of farm site}

The dairy farm (2200 milking cows) with $67 \mathrm{hm}^{2}$ of farm land was located near Beijing, China. The manure management on this farm is based on mechanical removal (scraping) of the cattle slurry from the solid floors and subsequent separation of the slurry (screw press). The end products of the slurry treatment system are a solid fraction that is further processed by a composting firm, and a liquid fraction that is applied to nearby agricultural land. The applied techniques of floor scraping and manure separation for dairy farms have been described by several authors ${ }^{[4-9]}$. In more detail, the dairy farm uses the following manure management technologies:

- Solid concrete floors with automatic slurry scrapers (scraped every $40 \mathrm{~min}$ );

- Collection and transport of the scraped slurry in underground manure channels

- Flushing of the manure channels with liquid fraction from slurry separation;

- Transport of the scraped slurry through manure channels to a slurry separator (inclined screen and screw press, see Figure 1);

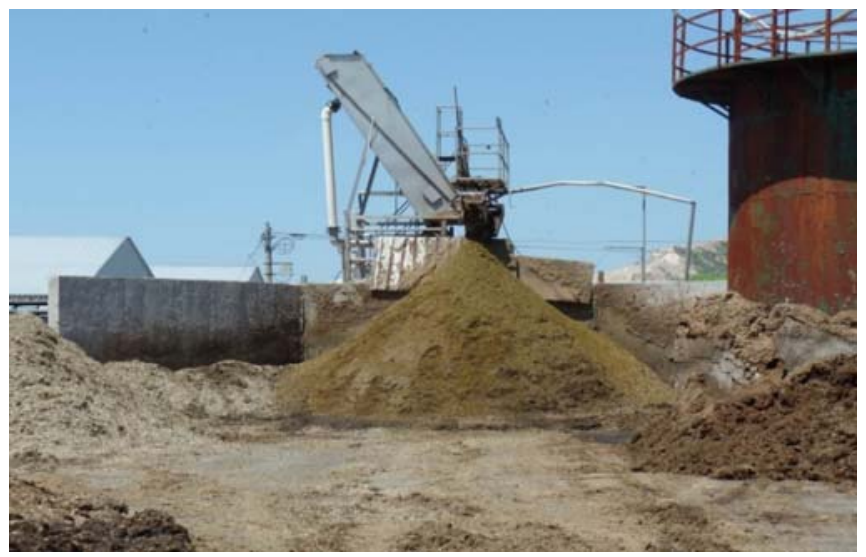

Figure 1 Slurry separation by inclined screen and screw press

- Storage of the liquid fraction in covered lagoons (during approx. 6 months);
- Application of liquid fraction on adjacent agricultural land by irrigation channels;

- Liquid fraction is applied twice a year to $67 \mathrm{hm}^{2}$ of farm land (wheat and corn).

The solid fraction from the manure separation is transferred to a composting company and subsequently sold as organic fertilizer to vegetable farms in the region. The liquid fraction is stored in covered lagoons (Figure 2).

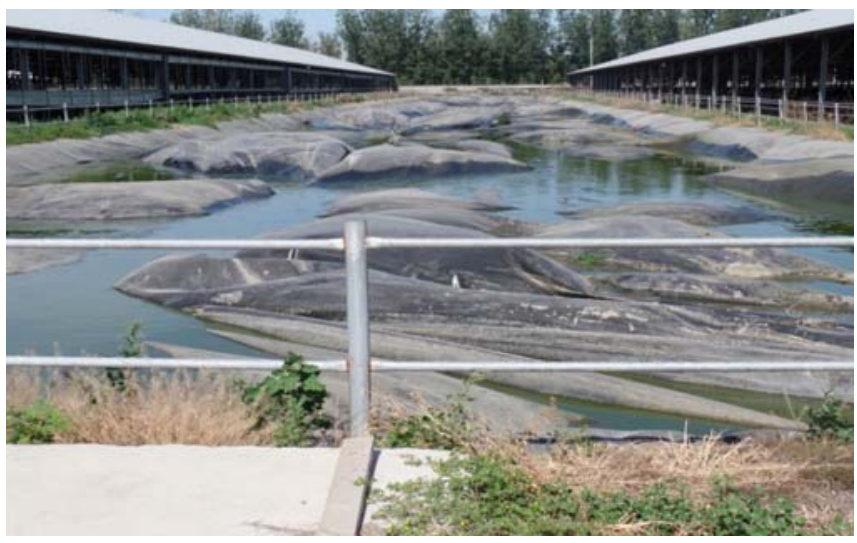

Figure 2 A covered lagoon for storage of the liquid fraction from the slurry separator (on top of the cover, some rainwater has accumulated)

\section{Emissions of ammonia and nitrous oxide from scraped floors}

An important source of gaseous nitrogen emissions are the losses of ammonia $\left(\mathrm{NH}_{3}\right)$ and nitrous oxide $\left(\mathrm{N}_{2} \mathrm{O}\right)$ from the scraped solid floors of the animal house ${ }^{[10-12]}$. These emissions were estimated by measuring these compounds with a closed flux chamber and a multigas-analyzer on this farm ${ }^{[13]}$.

The $\mathrm{NH}_{3}$ emission was estimated at $4.2 \mathrm{~kg} \mathrm{NH}$ per milking cow per year and the $\mathrm{N}_{2} \mathrm{O}$ emission at about $0.1 \mathrm{~kg} \mathrm{~N}_{2} \mathrm{O}$ per milking cow per year. In total of this represents a nitrogen loss of $3.5 \mathrm{~kg} \mathrm{~N}$ per milking cow per year $^{[13]}$.

\section{Slurry production, slurry separation and corresponding nutrient levels}

Based on literatures ${ }^{[13-15]}$, the nutrient excretion of the cows and the corresponding amounts and levels of the solid and liquid fraction after slurry separation are estimated (Table 1). For the calculation, it is assumed that the manure production (ton per milking cow per year) 
in China and in the Netherlands are the same (comparable milk production levels), that the manure from large scale intensive cattle farms in China has the same nutrient levels as in the Netherlands (comparable diet compositions), and that screw press filters in China have a comparable separation performance as screw press filters in the Netherlands. The main input for the calculations are the results of cattle slurry separation tests with a screw press separator that were carried out on 13 Dutch dairy farms ${ }^{[14]}$.

Table 1 Manure characteristics, nutrient balance and manure separator performance for a cattle farm, as based on literatures ${ }^{[13-15]}$

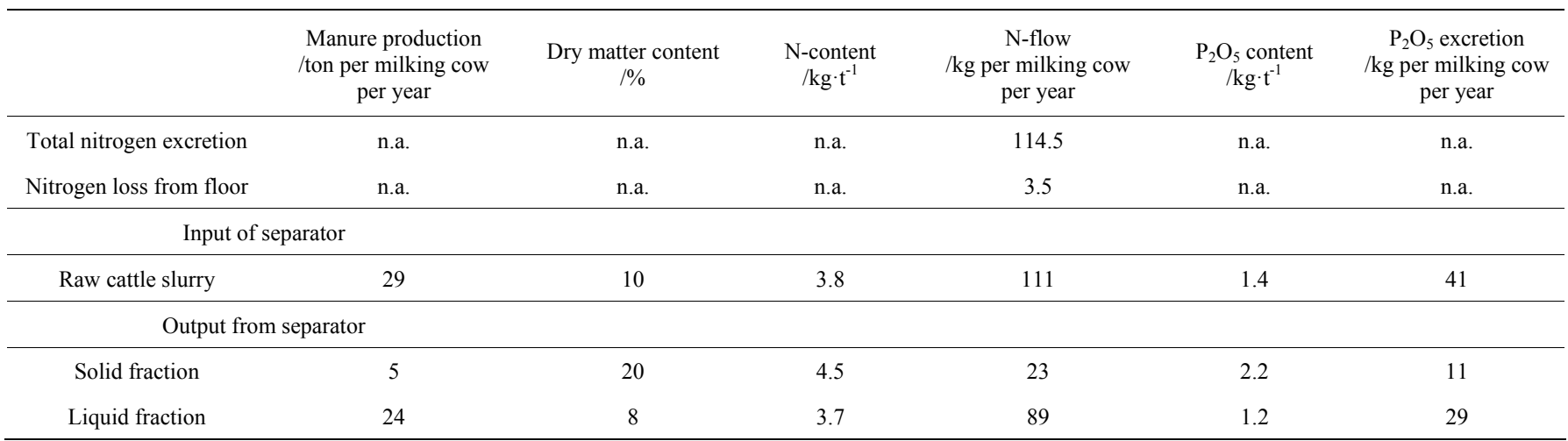

Note: $\mathrm{N}=$ nitrogen; $\mathrm{P}_{2} \mathrm{O}_{5}=$ phosphate; n.a.= not applicable.

Based on the measured nutrient levels of the aforementioned study ${ }^{[14]}$ and the assumed manure production rate ${ }^{[15]}$, the total amount of nitrogen in the manure entering the separator can be estimated, viz $111 \mathrm{~kg} \mathrm{~N}$ per milking cow per year. As described in the previous section, the nitrogen loss from the floors is estimated to be $3.5 \mathrm{~kg} \mathrm{~N}$. This means that the total nitrogen excretion per milking cow per year is the sum of these two and amounts to $111+3.5=114.5 \mathrm{~kg} \mathrm{~N}$.

One highly productive milking cow (milk production $\approx 10000 \mathrm{~kg} /$ year) produces $29 \mathrm{t}$ of raw slurry per year ${ }^{[15]}$; separation of the raw slurry produces $5 \mathrm{t}(16 \%)$ of solid fraction and $24 \mathrm{t}(84 \%)$ of liquid fraction per milking cow

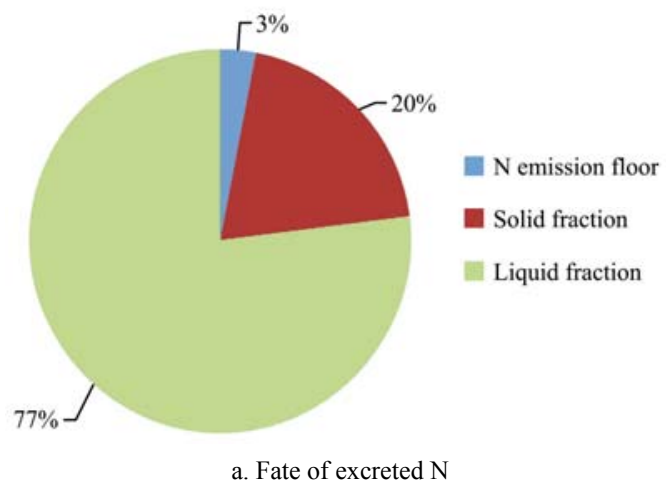

per year ${ }^{[14]}$. The solid fraction with $20 \%$ dry matter is stackable and no liquid runs out of the pile.

After slurry separation with a screw press, $79 \%$ of the nitrogen and $73 \%$ of the phosphate remain in the liquid fraction $^{[14]}$. These percentages can vary with the type of separator and the type of slurry.

Furthermore, in Figure 3, pie charts are given to illustrate the total amount of nitrogen and phosphate $(100 \%)$ that is excreted by the cows and where this ends up. It shows what part is emitted from the floor (for nitrogen) and how the remaining nitrogen and phosphate is distributed between solid and liquid fraction. For phosphate there is supposed to be no emission.

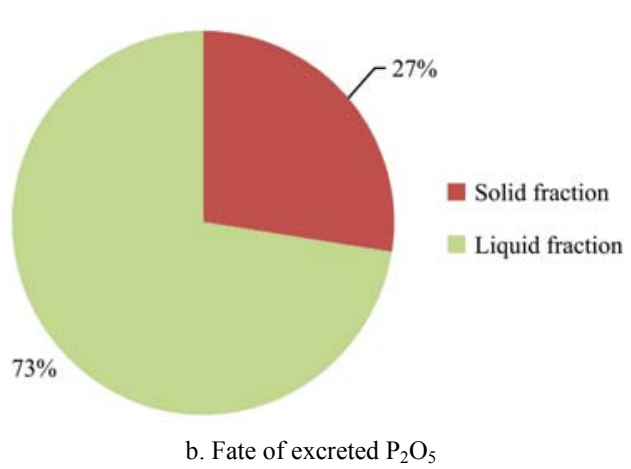

Figure 3 Calculated distribution of nitrogen and phosphate for floor emission $(\mathrm{N})$ and slurry separation $\left(\mathrm{N}\right.$ and $\left.\mathrm{P}_{2} \mathrm{O}_{5}\right)$

\section{Storage of the liquid fraction in covered}

\section{lagoons}

After slurry separation, the liquid fraction (i.e. $84 \%$ of the original slurry volume) is stored in covered lagoons until the moment of land application (Figure 2). The average storage period is around 6 months, since two crops per year can be grown in the Beijing region. 
The nitrogen loss to the atmosphere from an uncovered lagoon can be $70 \%-90 \%$, but by covering the lagoon, this emission of $\mathrm{NH}_{3}$ can be reduced by $80 \%{ }^{[16]}$, resulting in an remaining gaseous nitrogen loss of approx. $15 \%$ from prolonged storage in a covered lagoon. During prolonged storage, phosphate sedimentation into a sludge on the bottom of the lagoon can reduce the phosphate content of the liquid fraction by $50 \%-80 \%$, depending on the degree of agitation during pumpout ${ }^{[17]}$. In our further calculations, we assume a reduction of $70 \%$ in phosphate content and of $20 \%$ in nitrogen content of the manure due to sedimentation during lagoon storage. This means that a considerable amount of the phosphate, and to a lesser extent also nitrogen, accumulates at the bottom of the lagoon. The total nitrogen loss during lagoon storage $(15 \%$ to the atmosphere and $20 \%$ into sludge) is assumed to be $35 \%$.

As a result, the nitrogen and phosphate levels in the liquid fraction after lagoon storage, at the moment of land application, will be around $2.4 \mathrm{~kg} \mathrm{~N} / \mathrm{t}$ and $0.36 \mathrm{~kg} \mathrm{P}_{2} \mathrm{O}_{5} / \mathrm{t}$.

\section{Application of the liquid fraction to agricultural land}

After storage the liquid fraction is pumped out of the lagoons and transported to the fields using trucks. Then the slurry is distributed on the land using irrigation. The cropping system is a winter wheat-summer maize rotation system, with wheat planted in mid-October after the harvest of maize. The slurry is applied in July and in November/December.

The nitrogen efficiency of liquid manure application by irrigation without incorporation into the soil is estimated at $20 \%-40 \%$ of the remaining nitrogen after storage ${ }^{[18]}$. In our calculation, we assume a $30 \%$ $\mathrm{N}$-efficiency; this means that $70 \%$ of the nitrogen is lost during and after land application, mainly as volatilization of ammonia. The phosphate efficiency is assumed to be $100 \%$ of the remaining phosphate in the liquid fraction after sedimentation during lagoon storage. It is assumed that the sludge, remaining on the lagoon bottom after emptying the lagoon, eventually will be collected and transferred to a recipient outside the dairy company (e.g. to a composting company or vegetable farm).
In Figure 4 the results of the calculations are shown for the nitrogen and phosphate distribution between the different sinks and emissions, with the nitrogen and phosphate load of the liquid fraction from the screw-press as input. For the pie charts clearly show that effectively $20 \%$ of all nitrogen and $30 \%$ of all phosphate can be taken up by the crops grown on the adjacent $67 \mathrm{hm}^{2}$ of agricultural land.

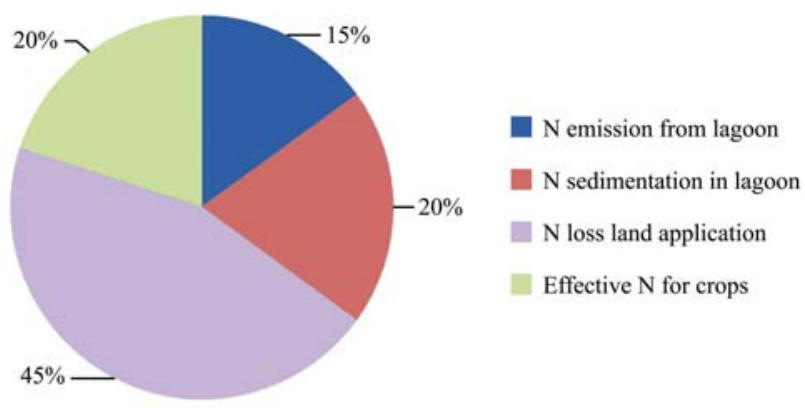

a. Fate of $\mathrm{N}$ in liquid fraction

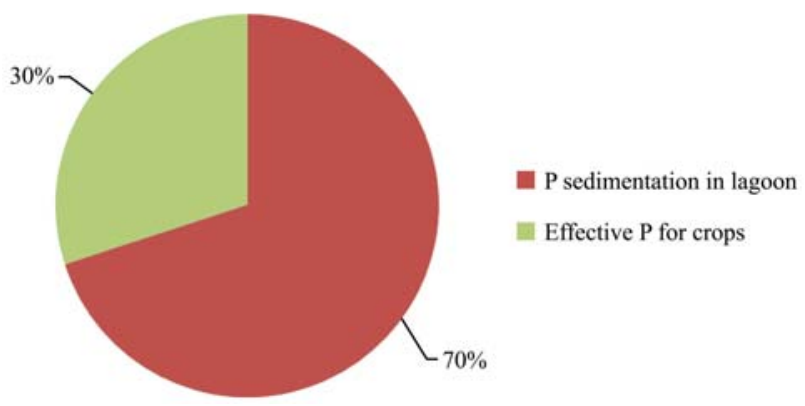

b. Fate of $\mathrm{P}_{2} \mathrm{O}_{5}$ in liquid fraction

Figure 4 Calculated fate and distribution of nitrogen $(\mathrm{N})$ and phosphate $\left(\mathrm{P}_{2} \mathrm{O}_{5}\right)$ from liquid fraction, taking into account gaseous $\mathrm{N}$-emission, sedimentation losses during lagoon storage and losses during land application

\section{Discussion}

Taking into consideration storage losses of $35 \%$ of the nitrogen and $70 \%$ of the phosphate and an efficiency of $30 \%$ for the remaining nitrogen during and after land application, as discussed above, the fertilization of $67 \mathrm{hm}^{2}$ of agricultural land with the liquid fraction from 2200 cattle results in application rates of $570 \mathrm{~kg}$ effective $\mathrm{N} /\left(\mathrm{hm}^{2} \cdot \mathrm{a}\right)$ and $285 \mathrm{~kg} \mathrm{P}_{2} \mathrm{O}_{5} /\left(\mathrm{hm}^{2} \cdot \mathrm{a}\right)$ (Table 2). This is based on the assumption that the sedimentary sludge is eventually collected and disposed of to an external customer, just as the solid fraction from the separator.

When, on the other hand, all sedimentary nutrients are mixed up with the liquid fraction used for irrigation (e.g., after vigorous agitation and flushing during lagoon pumpout), and thus all nutrients are applied to the 
adjacent agricultural land, this would result in application rates of $755 \mathrm{~kg}$ effective $\mathrm{N} /\left(\mathrm{hm}^{2} \cdot \mathrm{a}\right)$ and $960 \mathrm{~kg}$ $\mathrm{P}_{2} \mathrm{O}_{5} /\left(\mathrm{hm}^{2} \cdot \mathrm{a}\right)$ (Table 2). Especially for $\mathrm{P}_{2} \mathrm{O}_{5}$ this would mean a drastic increase.

Table 2 Calculated application rates for nitrogen and phosphate for a dairy farm with 2200 milking cows and $67 \mathrm{hm}^{2}$ of agricultural land, using liquid fraction from manure separation, after storage in covered lagoon

\begin{tabular}{ccc}
\hline $\begin{array}{c}\text { Manure used for } \\
\text { fertilization }\end{array}$ & $\begin{array}{c}\text { Nitrogen application rate } \\
/ \mathrm{kg} \text { effective } \mathrm{N} \cdot\left(\mathrm{hm}^{2} \cdot \mathrm{a}\right)^{-1 *}\end{array}$ & $\begin{array}{c}\text { Phosphate application } \\
\text { rate }\end{array}$ \\
$/ \mathrm{kg} \mathrm{P}_{2} \mathrm{O}_{5} \cdot\left(\mathrm{hm}^{2} \cdot \mathrm{a}\right)^{-1}$
\end{tabular}

Note: The manure production of young stock, estimated at $12 \mathrm{~m}^{3}$ of slurry per animal per year, has not been taken into account ${ }^{[12]}$. Therefore, the calculated application rates in Table 2 are probably underestimates.

*Effective $\mathrm{N}$ means the $\mathrm{N}$ that is available for the crops, i.e. losses during and after land application are deducted.

The calculated manure nitrogen and phosphorus application rates, after storage and application losses (Table 2, first row), are quite high as compared to the maximum application rates that are used in the Netherlands (Maximum effective nitrogen application rate (successive wheat and corn crops in same year): 252-335 $\mathrm{kg} \mathrm{N} /\left(\mathrm{hm}^{2} \cdot \mathrm{a}\right)$ (depending on soil type) ${ }^{[19]}$; maximum phosphate application rate for arable land: 50-75 $\mathrm{kg} \mathrm{P}_{2} \mathrm{O}_{5} /\left(\mathrm{hm}^{2} \cdot \mathrm{a}\right.$ ) (depending on soil phosphate condition $\left.)^{[19]}\right)$. In the Netherlands, the maximum application rates are based on 'equilibrium fertilization', i.e. the application rate must be in balance with the nutrient uptake by the crop in order to minimize avoidable losses to soil and water ${ }^{[20]}$. The higher application rates shown in Table 2 might to some extent be justified by higher yields, higher crop uptake, different soil conditions and a longer growing season with two crops per year in the Beijing region.

When, on the other hand, all nutrients from the lagoons are applied to agricultural land (with complete mixing of the lagoon content during pumpout) much higher application rates are calculated, especially for phosphate (Table 2, second row). The phosphate application rate of $960 \mathrm{~kg} /\left(\mathrm{hm}^{2} \cdot \mathrm{a}\right)$ is more than ten times higher than the maximum phosphate application rate for arable land in the Netherlands. Furthermore, we must keep in mind that Table 2 is based on application of manure nutrients only: if additional synthetic fertilizer is used, which is often the case in practice; this will inevitably further increase the nutrient application rates. In addition, the manure production from young stock has not been taken into account, which would also increase the application rates.

\section{Conclusions and recommendations}

Although the calculated application rates for nitrogen and phosphate are based on several assumptions that were not specifically validated for Chinese conditions, we conclude that there is a large risk of over-fertilization, resulting in pollution of soil and water. Currently, specific information on manure production levels, nutrient levels in manure fractions, nutrient losses during lagoon storage, nutrient losses during and after land application, on nutrient removal by crops, etc. for Chinese conditions is limited. When new data becomes available in future, the calculations that were done in this paper could be improved and help to further determine optimal nutrient application rates for animal manure under Chinese circumstances.

In our opinion, further research and extension should be aimed at increasing the manure nutrient efficiency. This means that losses to the environment (e.g. to groundwater tables, surface water, air) are minimized and a larger part of the minerals is taken up by the crops. Besides reducing the environmental impact, increasing the manure nutrient would also means that farmers' expenses for chemical fertilizer purchase can be reduced.

We suggest to establish recommended and maximum nutrient application rates for nitrogen and phosphate from animal manure in China. These application rates may be differentiated with regard to crop and soil types and different climate zones in China. In the meantime, provisional application standards could be established for nitrogen and phosphate fertilization (from both animal manure and chemical fertilizers). In this way, all stakeholders (farmers, extension, officials, etc.) can gain experience with using application standards. Experiences in the Netherlands and other countries show 
that a combination of legislation and enforcement is essential to achieve the set goals and to prevent dumping of large manure volumes on small areas of agricultural land.

Currently, chemical analyses of the nutrient ( $\mathrm{N}$ and $\mathrm{P}_{2} \mathrm{O}_{5}$ ) contents of cattle slurry, anaerobic digester effluent, solid and liquid fractions and other manure products, are often lacking in Chinese agriculture. However, these values are essential for the calculation of accurate crop specific fertilization rates, or the calculation of how much manure can be adequately utilized per hectare. So the development and dissemination of knowledge on nutrient levels in organic fertilizers in relation to the nutritional needs of crops is highly desirable in our opinion. This includes the interpretation by farm managers of the results of chemical analysis of organic fertilizers and soils.

Finally, we recommend to combining and summarizing this information and knowledge in farm-specific 'Manure Nutrient Management Plans'. The main element in such a plan is, as we illustrated in this paper, a calculation on how much manure and nutrients are produced per year, how this manure is treated or utilized on the farm or what happens with it when it is transported to other (crop) farms or companies. Logically the plans for application of manure to crops should include a calculation of manure and nutrients application rates.

\section{Acknowledgements}

This project was supported by the Ministry of Economic Affairs of the Netherlands through the TKI AF14247 Sino-Dutch Dairy Development Center (SDDDC) program (BO-27.04-001-014) by the Beijing Municipal Science and Technology Plan Project (D151100005115001).

\section{[References]}

[1] Tan B, Yin Y. Environmental sustainability analysis and nutritional strategies of animal production in China. Annual Review of Animal Biosciences, 2017; 5: 171-184.

[2] Chadwick D R, Jia W, Tong Y, Yu G H, Shen Q R, Chen Q. Improving manure nutrient management towards sustainable agricultural intensification in China. Agriculture,
Ecosystems \& Environment, 2015; 209: 34-46.

[3] Li S, Liu K, Liu X (Eds). White paper on China dairy 2014. Sino-Dutch Dairy Development Centre. http://www.sdddc.org/en/download/detail-137.aspx

[4] $\mathrm{Wu} \mathrm{Z}$. Phosphorus and nitrogen distribution of screw press separated dairy manure with recovery of bedding material. Applied Engineering in Agriculture, 2007; 23: 757-762.

[5] Møller H B, Lund I, Sommer S G. Solid-liquid separation of livestock slurry: efficiency and cost. Bioresource Technology, 2000; 74: 223-229.

[6] Hjorth M, Christensen K V, Christensen M L, Sommer S G. Solid-liquid separation of animal slurry in theory and practice. A review. Agronomy for Sustainable Development, 2010; 30: $153-180$.

[7] Møller H B, Sommer S G, Ahring B K. Separation efficiency and particle size distribution in relation to manure type and storage conditions. Bioresource Technology, 2002; 85: 189-196.

[8] Ogink N W M, Kroodsma W. Reduction of ammonia emission from a cow cubicle house by flushing with water or a formalin solution. Journal of Agricultural Engineering Research; 1996; 63: 197-204.

[9] Braam C R, Ketelaars J J M H, Smits M C J. Effects of floor design and floor cleaning on ammonia emission from cubicle houses for dairy cows. Netherlands Journal of Agricultural Science, 1997; 45: 49-64.

[10] Baldinia C, Borgonovob F, Guarino M. Comparison among $\mathrm{NH}_{3}$ and GHGs emissive patterns from different housing solutions of dairy farms. Atmospheric Environment, 2016; 141: 60-66.

[11] Wu W, Zhang G, Kai P. Ammonia and methane emissions from two naturally ventilated dairy cattle buildings and the influence of climatic factors on ammonia emissions. Atmospheric Environment, 2012; 61: 232-243.

[12] Zhang G, Strøm J S, Li B, Rom H B, Morsing S, Dahl P, Wang C. Emission of ammonia and other contaminant gases from naturally ventilated dairy cattle buildings. Biosystems Engineering, 2005; 92: 355-364.

[13] Melse R W, de Buisonjé F E. Indicative emission measurements at two dairy farms in the Beijing region, China. Project report WP5 - Sino-Dutch Dairy Development Centre SDDDC/ Wageningen University and Research, Wageningen, the Netherlands, 2016; 34p.

[14] Verloop J, Hilhorst G J, Meerkerk B, de Buisonjé F E, Schröder J J, de Haan M H A. Mestscheiding op melkveebedrijven; resultaten van MOBIEDIK, Mobiele Mestscheiding in Dik en Dun (Manure separation on dairy farms: results of the MOBIEDIK mobile manure separator), in Dutch. Rapport 284. Wageningen UR/ Plant Research 
International, Wageningen, the Netherlands, 2009; 59p.

[15] KWIN 2016-2017. Quantitative information for animal husbandry. Wageningen UR Livestock Research, the Netherlands, 2016; 340p.

[16] Leytem A B, Dungan R S. Livestock GRACEnet: A workgroup dedicated to evaluating and mitigating emissions from livestock production. Journal of Environmental Quality, 2014; 43: 1101-1110.

[17] Fulhage C D, Pfost D L, Schuster D L. Fertilizer nutrients in livestock and poultry manure. University of Missouri
Cooperative Extension Bulletin EQ 351. 2002.

[18] Rotz C A. Management to reduce nitrogen losses in animal production. Anim Sci, 2004; 82 E-Suppl: E119-137.

[19] RVO. Manure policy 2014-2016 - Supporting tables (Tabellenbrochure Mestbeleid), in Dutch, Table 1 and 2, 2016. http://www.rvo.nl/onderwerpen/agrarisch-ondernemen/ mest-en-grond/mest/tabellen-en-publicaties.

[20] De Buisonjé F E, Melse R W, Hoeksma P. Handling animal manure, the struggle of the Netherlands. World Environment, 2016; 2: 41-45. (in Chinese) 